\title{
BRAZILIAN VODKAS HAVE UNDETECTABLE LEVELS OF ETHYL CARBAMATE
}

\author{
Elainy V. S. Pereira, Sonia P. A. Oliveira and Ian C. C. Nóbrega*\# \\ Departamento de Tecnologia Rural, Universidade Federal Rural de Pernambuco, 52171-900 Recife - PE, Brasil \\ Dirk W. Lachenmeier
}

Chemisches und Veterinäruntersuchungsamt Karlsruhe, Weissenburger Strasse 3, 76187 Karlsruhe, Germany

Adelia C. P. Araújo, Danuza L. Telles and Marileide Silva

Laboratório de Agrotóxicos e Contaminantes em Alimentos e Bebidas Alcoólicas, Instituto de Tecnologia de Pernambuco, 50740-540 Recife - PE, Brasil

Recebido em 25/9/12; aceito em 21/1/13; publicado na web em 14/5/13

\begin{abstract}
While in Europe vodka is mainly derived from potatoes or cereals, a large proportion of Brazilian vodka is likely obtained from sugarcane, which contains ethyl carbamate (EC) precursors. EC, in addition to several other contaminants and congeners, were investigated in 32 samples of Brazilian vodka. All samples complied with the Brazilian regulations for congeners and contaminants, having EC content below $0.01 \mathrm{mg} / \mathrm{L}$ (detection limit). These results are probably related to the processing of vodka, in particular the use of extractive and rectifying stainless steel distillation columns, which allow the production of high strength spirits with low levels of congeners and contaminants.
\end{abstract}

Keywords: vodka; contaminants; congeners.

\section{INTRODUCTION}

Ethyl carbamate $\left(\mathrm{EC}, \mathrm{C}_{2} \mathrm{H}_{5} \mathrm{OCONH}_{2}\right)$, a multi-site carcinogen in experimental animals and probably carcinogenic to humans, ${ }^{1}$ occurs in many fermented foods, particularly spirit beverages, where it is thought to be formed from the reaction between ethanol and hydrogen cyanide derived from cyanogenic materials ${ }^{2}$. These materials include stone-fruits or sugarcane, ${ }^{3}$ both of which are associated with a high incidence of EC in cherry or plum spirits ${ }^{4}$ as well as in cachaça (Brazilian sugarcane spirit)..$^{5-8}$

As a result, in-line with legislation in other countries, Brazil established an EC limit $(0.15 \mathrm{mg} / \mathrm{L})$ for cachaça. ${ }^{9}$ However, other alcoholic beverages, including vodka, are not submitted to EC regulation in Brazil.

Although vodkas from different countries are generally regarded to contain low EC levels, ${ }^{10-13}$ some conflicting results on vodka emerged from European Food Safety Authority data in 2007. ${ }^{2}$ With regard to Brazilian vodkas, levels of EC are unknown.

According to Brazilian regulations, vodka is a beverage bottled at between $36 \%$ and $54 \%$ alcohol by volume (vol.) prepared from potable ethyl alcohol of agricultural origin. ${ }^{14}$ The latter must be obtained from the distillation and/or rectification, after alcoholic fermentation, of agricultural raw materials (starchy or sugary), produced at between $54 \%$ and $95 \%$ vol. ${ }^{15}$ Furthermore, in contrast to European regulation, ${ }^{16}$ Brazilian vodkas not produced from potatoes and/or cereals are not obliged to indicate the raw materials on labeling. Since sugarcane is the most viable agricultural feedstock in Brazil for the purpose, it is reasonable to assume that a large proportion of Brazilian vodkas, in particular cheap brands, is obtained from this cyanogenic raw material.

The Brazilian regulation for vodka ${ }^{14}$ also specifies maximum levels for volatile substances other than ethanol and methanol (total congeners, $50 \mathrm{mg} / 100 \mathrm{~mL}$ pure ethanol) and certain contaminants

*e-mail: ian@dtr.ufrpe.br

\#Programa de Pós-graduação em Ciência e Tecnologia de Alimentos da UFRPE (methanol, $20 \mathrm{mg} / 100 \mathrm{~mL}$ pure ethanol; copper, $5 \mathrm{mg} / \mathrm{L}$ vodka; lead, $0.2 \mathrm{mg} / \mathrm{L}$ vodka). On the other hand, EU regulation for vodka ${ }^{16}$ has its own maximum levels for various chemical residues, such as esters expressed as ethyl acetate $(1.3 \mathrm{mg} / 100 \mathrm{~mL}$ pure ethanol $)$, aldehydes expressed as acetaldehyde $(0.5 \mathrm{mg} / 100 \mathrm{~mL}$ pure ethanol $)$, methanol $(10 \mathrm{mg} / 100 \mathrm{~mL}$ pure ethanol) and higher alcohols expressed as 2-methyl-1-propanol $(0.5 \mathrm{mg} / 100 \mathrm{~mL}$ pure ethanol).

Based on the considerations outlined above, the aim of this paper was to investigate EC, together with several other contaminants (methanol, copper, and lead) and congeners (acetaldehyde, ethyl acetate, higher alcohols, and volatile acidity), in vodkas produced in Brazil and discuss the results in light of Brazilian and European regulations.

\section{EXPERIMENTAL}

Thirty-two (32) samples of recorded (licit) Brazilian vodkas were collected from a national beverage distributor/retailer (Imigrantes Mercantil Ltda, www.imigrantesbebidas.com.br) between May and December 2010. The sampling included 20 brands of Brazilian vodkas produced by 18 different companies. All vodkas were plain (unflavored) and colorless. According to the label information, 18 of the vodka brands listed potable ethyl alcohol as an ingredient but provided no indication of the agricultural raw material from which it was derived (only two brands are allegedly made entirely from cereal-derived ethyl alcohol). Brand prices (per liter of vodka) ranged from US $\$ 2.86$ to US\$12.83 (quality reference brand).

Ethyl carbamate, acetaldehyde, ethyl acetate, $n$-propanol, iso-butanol (2-methyl-1-propanol), iso-amyl alcohol (3-methyl-1-butanol), methanol, and 1-pentanol were purchased from Dr Ehrenstorfer (Augsburg, Germany). Sodium hydroxide from Merck (Darmstadt, Germany). Copper, lead, palladium nitrate and magnesium nitrate standard solutions were purchased from Fluka (Buchs, Switzerland). Ultra-pure water (Milli-Q system) or LC-grade ethanol (Merck, Darmstadt, Germany) at $40 \%$ vol. was used throughout to prepare solutions.

The alcoholic strengths ( $\%$ vol. at $\left.20{ }^{\circ} \mathrm{C}\right)$ of spirits were determined as described by our group previously. ${ }^{17}$ 
Volatile acidity as acetic acid was determined using an automatic DEE Gibertini distillation unit attached to a VADE3 Gibertini steam unit (Gibertini Elettronica, Milan, Italy). Samples $(10 \mathrm{~mL})$ were steam distilled, collected $(200 \mathrm{~mL})$ and submitted to titration with $\mathrm{NaOH}(0.02 \mathrm{~mol} / \mathrm{L})$ using phenolphthalein as the indicator. Results were expressed as $\mathrm{mg} / 100 \mathrm{~mL}$ pure ethanol.

EC analysis by Gas Chromatography coupled with Mass Spectrometry (GC-MS) was carried out as described by our group previously ${ }^{17}$ with some differences: sample injection and GC column were altered to $1 \mu \mathrm{L}$ and to a Carbowax 20M (Varian, $60 \mathrm{~m} \times 0.25 \mathrm{~mm}$ $\mathrm{x} 1 \mu \mathrm{m}$ film thickness). The limits of detection and quantification were 0.01 and $0.05 \mathrm{mg} / \mathrm{L}$, respectively.

Higher alcohols ( $n$-propyl, iso-butyl, and iso-amyl), acetaldehyde, ethyl acetate and methanol were determined by a Thermo/Trace GC Ultra gas chromatograph equipped with flame ionization detector (FID) and Carbowax 20M column (Varian, 60m x 0.25mm x $1 \mu \mathrm{m}$ film thickness), using ChromQuest 4.1 software. An autosampler was used to introduce $1 \mu \mathrm{L}$ aliquots of each vodka sample in splitless mode. The GC oven was initially kept at $60{ }^{\circ} \mathrm{C}$ and subsequently increased to $200{ }^{\circ} \mathrm{C}$ at $10{ }^{\circ} \mathrm{C} / \mathrm{min}$. The temperatures of injector and detector were set at 230 and $250{ }^{\circ} \mathrm{C}$, respectively. Quantification was based on calibration curves (analytical working solutions were prepared in ethanol $40 \%$ vol.) using 1-pentanol as the internal standard. Congeners were estimated by calculating the sum of volatile acidity, acetaldehyde, ethyl acetate, and higher alcohols. Results were expressed as $\mathrm{mg} / 100 \mathrm{~mL}$ pure ethanol.

$\mathrm{Cu}$ and $\mathrm{Pb}$ were determined using a Thermo Scientific GFS 97 atomic absorption spectrometer with deuterium-lamp background correction, SOLAAR software, equipped with a GFS 97 graphite-furnace/autosampler module. Vodka samples were introduced directly. Hollow cathode lamps (Photron, Australia) were used for the determination of $\mathrm{Cu}(249.2 \mathrm{~nm})$ and $\mathrm{Pb}(283.3 \mathrm{~nm})$ operated at 10 and $20 \mathrm{~mA}$, respectively. ${ }^{18}$ High-purity argon was used as the purge gas throughout at a flow rate of $200 \mathrm{~mL} / \mathrm{min}$. Other operating conditions were established according to recommendations of the manufacturer. Quantification was based on calibration curves [analytical working solutions $(0.1-2.0 \mathrm{mg} / \mathrm{L} \mathrm{Cu}$, and $10-80 \mu \mathrm{g} / \mathrm{L} \mathrm{Pb})$ were prepared in ethanol $40 \%$ vol.] and checked by standard addition.

\section{RESULTS AND DISCUSSION}

Table 1 shows results for alcoholic strength, $\mathrm{pH}$, volatile acidity, ethyl acetate, higher alcohols, total congeners and ethyl carbamate of 32 samples of Brazilian vodkas (ranked in increasing order of retail price, US\$2.86-US\$12.73) from a wide range of brands (20) and producers (18). Concentration ranges, median, mean and P95 ( $95^{\text {th }}$ percentile) of values, as well as limits established by Brazilian and European Union (EU) regulations for vodkas, are also presented in Table 1

Results for acetaldehyde, copper and lead are not shown in Table 1 because concentrations in all samples were below the analytical quantification limits $(1.8 \mathrm{mg} / 100 \mathrm{~mL}$ pure ethanol, $0.1 \mathrm{mg} / \mathrm{L}$, and $0.01 \mathrm{mg} / \mathrm{L}$, respectively). Vodka samples, therefore, complied with the Brazilian regulations for copper and lead (maximum of $5 \mathrm{mg} / \mathrm{L}$ and $0.2 \mathrm{mg} / \mathrm{L}$, respectively). ${ }^{14}$ Levels of these substances in Brazilian vodkas are in line with concentrations reported in vodkas from Hungary, Poland, Ukraine, Lithuania, and Vietnam. ${ }^{10-13}$

With respect to methanol results (not shown in Table 1), all vodka samples contained below $0.5 \mathrm{mg} / 100 \mathrm{~mL}$ of pure ethanol (analytical quantification limit), and therefore lay within limits allowed under Brazilian and EU regulations (20 and $10 \mathrm{mg} / 100 \mathrm{~mL}$ pure ethanol, respectively). ${ }^{14,16}$ Higher concentration ranges for methanol, however, have been reported in vodkas from Poland (nd-12 mg/100 ml pure ethanol),${ }^{11}$ Ukraine (0.6-7.4 mg/100 mL pure ethanol), ${ }^{12}$ Hungary and Lithuania (nd-20 mg/100 ml pure ethanol). ${ }^{13}$

A median of $37.6 \%$ vol. for alcoholic strength was found for vodkas from Brazil (Table 1), with most samples (91\%) compliant with Brazilian regulation.

Interestingly, most Brazilian vodkas had alkaline $\mathrm{pH}$ values, with median and mean $\mathrm{pH}$ of 8.1 and 7.9, respectively (Table 1). These values may be attributed to treatment by different additives for the adjustment of alkalinity (e.g. alkalinisation with $\mathrm{NaHCO}_{3}$, neutralization with $0.1 \mathrm{M} \mathrm{HCl}$ ), which enhance the softness of the vodka taste ${ }^{19,20}$ and may also explain the fact that the volatile acidity was undetected in most samples (Table 1).

With respect to ethyl acetate and higher alcohols in vodkas, aspects not controlled by Brazilian regulation, concentration ranges of $<\mathrm{LQ}-4.0 \mathrm{mg} / 100 \mathrm{~mL}$ pure ethanol and $0.6-4.5 \mathrm{mg} / 100 \mathrm{~mL}$ pure ethanol, respectively, were found (Table 1). When assessed according to EU regulations, Brazilian vodkas failed to comply with maximum allowances for higher alcohols (all samples exceeded $0.5 \mathrm{mg} / 100 \mathrm{~mL}$ pure ethanol) and, to a lesser extent, for ethyl acetate (34\% exceeded $1.3 \mathrm{mg} / 100 \mathrm{~mL}$ pure ethanol) (Table 1). However, taking into account the average levels of higher alcohols and ethyl acetate found in the vodka samples as well as the toxicological data for these compounds, ${ }^{21}$ our findings should not be interpreted as a public health problem to Brazilian consumers, but may have implications for vodka flavor.

Although levels of ethyl acetate and/or higher alcohols in most samples were not compliant with the EU regulation, levels for total congeners (range 1.1-7.5 mg/100 mL pure ethanol, median 3.2, Table 1) were well below the upper limit established by Brazilian regulation $\left(50 \mathrm{mg} / 100 \mathrm{~mL}\right.$ pure ethanol). ${ }^{14}$

All sampled vodkas contained ethyl carbamate (EC) at levels below the analytical detection limit $(0.01 \mathrm{mg} / \mathrm{L})$ and therefore complied with the international EC upper limit $(0.15 \mathrm{mg} / \mathrm{L})$ established or recommended by several countries for distilled spirits. ${ }^{2}$ The results for these Brazilian vodkas are in line with EC levels found in vodkas from Poland, ${ }^{10}$ the Ukraine, ${ }^{12}$ Vietnam, ${ }^{11}$ and EU Member States. ${ }^{2}$

In spirit drinks, EC is mainly formed when cyanogenic glycosides (present in raw materials during fermentation) are degraded through enzymatic action to cyanide, which is then oxidized to cyanate and reacts with ethanol in copper-catalyzed reactions. EC formation can occur before, during or after distillation. Given the low and high volatility of EC and cyanide, respectively, post-distillation formation of EC in spirits has been considered the most relevant step. In practical terms, prevention of EC contamination in spirits involves the diversion or fixation of volatile cyanide during distillation (via increased reflux rates and exposure to copper) to non- or less volatile products, such as insoluble cyanide or thiocyanate and EC. ${ }^{22}$

Considering that Brazilian vodkas are largely made from a raw material (sugarcane) associated with a high incidence of EC in cachaça, both pot still and column still types,${ }^{5-8}$ our results suggest that volatile cyanide and other possible nitrogen precursors derived from sugarcane have been adequately controlled in the vodka process.

The absence of EC as well as the compliance of vodka samples with Brazilian regulations are factors probably related to the production process of its main ingredient (ethyl alcohol of agricultural origin or neutral spirits), in particular the use of extractive and rectifying stainless steel distillation columns which allow production of high strength spirits with low levels of congeners, ${ }^{23}$ and possibly of contaminants. The distillation effect on congeners and other organic compounds may have been compounded by filtration of the raw spirit through activated charcoal, which has been shown to reduce EC levels in contaminated spirits. ${ }^{24}$ Charcoal filtration is a treatment permitted under both Brazilian and EU regulations for vodka.

The fact that $\mathrm{EC}$ has been found in large concentrations in column 
Table 1. Selected analysis results ${ }^{\mathrm{a}}$ (alcoholic strength, $\mathrm{pH}$, volatile acidity, ethyl acetate, higher alcohols, total congeners and ethyl carbamate) of 32 samples of Brazilian vodkas

\begin{tabular}{|c|c|c|c|c|c|c|c|c|c|}
\hline \multirow[b]{2}{*}{ Sample $^{\mathrm{b}}$} & \multirow[b]{2}{*}{ Vodka Brand ${ }^{\mathrm{b}}$} & \multirow[b]{2}{*}{ Origin $^{c}$} & \multirow{2}{*}{$\begin{array}{c}\text { Alcoholic } \\
\text { strength }(\% \\
\left.\text { vol. at } 20^{\circ} \mathrm{C}\right)\end{array}$} & \multirow[b]{2}{*}{$\mathrm{pH}$} & \multicolumn{4}{|c|}{$\mathrm{mg} / 100 \mathrm{~mL}$ pure ethanol } & \multirow{2}{*}{$\begin{array}{c}\text { Ethyl } \\
\text { carbamate } \\
(\mathrm{mg} / \mathrm{L})\end{array}$} \\
\hline & & & & & $\begin{array}{l}\text { Volatile } \\
\text { acidity }^{\mathrm{d}}\end{array}$ & $\begin{array}{c}\text { Ethyl } \\
\text { acetate }^{\mathrm{e}}\end{array}$ & $\begin{array}{c}\text { Higher } \\
\text { alcohols }^{\mathrm{f}}\end{array}$ & $\begin{array}{c}\text { Total } \\
\text { congeners }^{\mathrm{g}}\end{array}$ & \\
\hline 01 & $\mathrm{~A}$ & SP & 37.5 & 8.7 & nd & 3.1 & 1.4 & 4.5 & $<\mathrm{LD}$ \\
\hline 02 & A & SP & 37.4 & 9.4 & nd & $<\mathrm{LQ}$ & 1.8 & 2.4 & $<\mathrm{LD}$ \\
\hline 03 & $\mathrm{~B}$ & PB & 37.7 & 8.1 & nd & $<\mathrm{LQ}$ & 1.4 & 2.0 & $<\mathrm{LD}$ \\
\hline 04 & $\mathrm{C}$ & MG & 37.4 & 7.8 & 0.1 & $<\mathrm{LQ}$ & 1.7 & 2.4 & $<\mathrm{LD}$ \\
\hline 05 & $\mathrm{C}$ & MG & 37.4 & 8.1 & nd & $<\mathrm{LQ}$ & 1.2 & 1.7 & $<\mathrm{LD}$ \\
\hline 06 & $\mathrm{D}$ & RS & 39.0 & 8.1 & nd & 3.0 & 1.4 & 4.4 & $<\mathrm{LD}$ \\
\hline 07 & $\mathrm{E}$ & MG & 39.0 & 8.4 & nd & 4.0 & 2.4 & 6.4 & $<\mathrm{LD}$ \\
\hline 08 & $\mathrm{~F}$ & SP & 36.7 & 8.0 & nd & 3.0 & 4.5 & 7.5 & $<\mathrm{LD}$ \\
\hline 09 & $\mathrm{G}$ & $\mathrm{PE}$ & 38.0 & 7.0 & 1.5 & 3.2 & 1.3 & 6.0 & $<\mathrm{LD}$ \\
\hline 10 & $\mathrm{H}$ & SP & 37.4 & 8.2 & nd & $<\mathrm{LQ}$ & 1.3 & 1.9 & $<\mathrm{LD}$ \\
\hline 11 & I & SP & 38.6 & 8.2 & nd & $<\mathrm{LQ}$ & 1.7 & 2.2 & $<\mathrm{LD}$ \\
\hline 12 & I & SP & 38.5 & 8.3 & nd & $<\mathrm{LQ}$ & 0.6 & 1.1 & $<\mathrm{LD}$ \\
\hline 13 & $\mathrm{~J}$ & SP & 36.8 & 7.0 & 1.6 & $<\mathrm{LQ}$ & 1.7 & 3.9 & $<\mathrm{LD}$ \\
\hline 14 & $\mathrm{~J}$ & SP & 36.7 & 7.1 & 1.5 & $<\mathrm{LQ}$ & 1.2 & 3.3 & $<\mathrm{LD}$ \\
\hline 15 & $\mathrm{~K}$ & SP & 38.7 & 8.2 & nd & 2.7 & 1.4 & 4.2 & $<\mathrm{LD}$ \\
\hline 16 & K & SP & 38.7 & 8.2 & nd & $<\mathrm{LQ}$ & 1.2 & 1.7 & $<\mathrm{LD}$ \\
\hline 17 & $\mathrm{~L}$ & SP & 37.8 & 7.1 & 1.5 & $<\mathrm{LQ}$ & 1.4 & 3.4 & $<\mathrm{LD}$ \\
\hline 18 & $\mathrm{~L}$ & SP & 37.9 & 7.1 & 1.5 & $<\mathrm{LQ}$ & 1.1 & 3.1 & $<\mathrm{LD}$ \\
\hline 19 & $\mathrm{M}$ & $\mathrm{SC}$ & 37.1 & 8.2 & nd & $<\mathrm{LQ}$ & 1.8 & 2.3 & $<\mathrm{LD}$ \\
\hline 20 & $\mathrm{M}$ & SC & 36.6 & 8.3 & nd & $<\mathrm{LQ}$ & 1.3 & 1.8 & $<\mathrm{LD}$ \\
\hline 21 & $\mathrm{~N}$ & $\mathrm{RS}$ & 37.5 & 8.0 & nd & $<\mathrm{LQ}$ & 1.4 & 1.9 & $<\mathrm{LD}$ \\
\hline 22 & $\mathrm{~N}$ & $\mathrm{RS}$ & 37.5 & 7.8 & 0.1 & $<\mathrm{LQ}$ & 1.8 & 2.4 & $<\mathrm{LD}$ \\
\hline 23 & $\mathrm{O}$ & SP & 35.4 & 8.3 & nd & 3.2 & 1.5 & 4.7 & $<\mathrm{LD}$ \\
\hline 24 & $\mathrm{O}$ & SP & 35.5 & 8.4 & nd & $<\mathrm{LQ}$ & 1.7 & 2.3 & $<\mathrm{LD}$ \\
\hline 25 & $\mathrm{P}$ & SP & 37.8 & 9.0 & nd & 3.0 & 1.4 & 4.4 & $<\mathrm{LD}$ \\
\hline 26 & Q & SP & 35.4 & 7.4 & 1.9 & 3.1 & 1.5 & 6.5 & $<\mathrm{LD}$ \\
\hline 27 & $\mathrm{R}$ & SP & 38.7 & 7.7 & 0.5 & $<\mathrm{LQ}$ & 1.8 & 3.3 & $<\mathrm{LD}$ \\
\hline 28 & $\mathrm{R}$ & SP & 38.6 & 7.4 & 1.0 & $<\mathrm{LQ}$ & 1.7 & 3.1 & $<\mathrm{LD}$ \\
\hline 29 & $\mathrm{~S}$ & $\mathrm{RJ}$ & 37.8 & 7.5 & 0.9 & $<\mathrm{LQ}$ & 1.4 & 2.8 & $<\mathrm{LD}$ \\
\hline 30 & $S$ & $\mathrm{RJ}$ & 37.8 & 7.0 & 2.3 & $<\mathrm{LQ}$ & 1.7 & 4.5 & $<\mathrm{LD}$ \\
\hline 31 & $\mathrm{~T}$ & SP & 37.6 & 7.0 & 1.9 & 3.0 & 1.4 & 6.3 & $<\mathrm{LD}$ \\
\hline \multirow[t]{5}{*}{32} & $\mathrm{~T}$ & SP & 37.4 & 6.2 & 3.0 & 0.6 & 1.8 & 5.4 & $<\mathrm{LD}$ \\
\hline & & Range & $35.4-39.0$ & $6.2-9.4$ & nd-3.0 & $<\mathrm{LQ}-4.0$ & $0.6-4.5$ & $1.1-7.5$ & - \\
\hline & & Median & 37.6 & 8.1 & $0.0^{\mathrm{j}}$ & $0.6^{\mathrm{k}}$ & 1.4 & 3.2 & - \\
\hline & & Mean & 37.6 & 7.9 & $0.6^{\mathrm{j}}$ & $1.4^{\mathrm{k}}$ & 1.6 & 3.6 & - \\
\hline & & $\mathrm{P} 95^{\mathrm{i}}$ & 38.8 & 8.8 & $2.1^{\mathrm{j}}$ & $3.2^{\mathrm{k}}$ & 2.1 & 6.4 & - \\
\hline \multicolumn{3}{|c|}{ Limits by Brazilian regulation ${ }^{1}$} & $36-54$ & - & - & - & - & $\leq 50$ & - \\
\hline \multicolumn{3}{|c|}{ Limits by EU regulation ${ }^{1}$} & $\geq 37.5$ & - & - & $\leq 1.3$ & $\leq 0.5$ & - & - \\
\hline
\end{tabular}

aLevels of methanol, acetaldehyde, copper, and lead are not shown in table 1 because concentrations in all samples were below quantification limits $(0.5 \mathrm{mg} / 100 \mathrm{~mL}$ pure ethanol, $1.8 \mathrm{mg} / 100 \mathrm{~mL}$ pure ethanol, $0.1 \mathrm{mg} / \mathrm{L}$, and $0.01 \mathrm{mg} / \mathrm{L}$, respectively). ${ }^{\mathrm{b}}$ Samples/brands are presented in increasing order of retail prices per litre of product (brand A, US $\$ 2.86$; brand T, US $\$ 12.73$; brands S and T are generally regarded as quality reference in Brazil). 'Production origin of vodkas are given as postal abbreviations of Brazilian States: SP, São Paulo; PB, Paraíba; MG, Minas Gerais; PE, Pernambuco; SC, Santa Catarina; RS, Rio Grande do Sul; RJ, Rio de Janeiro. ${ }^{d}$ Volatile acidity as acetic acid; nd, volatile acidity not detected (end-point of titration by dilute alkali solution was immediate). ${ }^{\text {eLimit }}$ of quantifica-

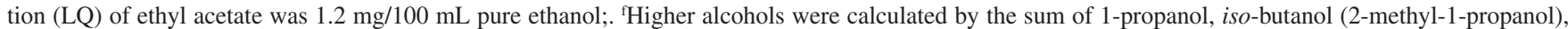
and amyl alcohols (2- + 3-methyl-1-butanol). ${ }^{9}$ Total congeners was estimated by the sum of volatile acidity, ethyl acetate, and higher alcohols, assuming <LQ (ethyl acetate) was $0.6 \mathrm{mg} / 100 \mathrm{~mL}$ pure ethanol. ${ }^{\mathrm{h}}$ Limit of detection (LD) of ethyl carbamate was $0.01 \mathrm{mg} / \mathrm{L} .{ }^{\mathrm{i}} \mathrm{P} 95$ is the $95^{\text {th }}$ percentile of values. ${ }^{\mathrm{j}} \mathrm{Median}$, mean and P95 of volatile acidity were estimated assuming nd $=0$ (volatile acidity). ${ }^{\mathrm{k}}$ Median, mean and P95 of ethyl acetate were estimated assuming $<\mathrm{LQ}=$ $0.6 \mathrm{mg} / 100 \mathrm{~mL}$ pure ethanol. 'Limits established by Brazilian and European Union (EU) regulations for vodka ${ }^{14,16}$; -, limits not established for the parameter.

still cachaça, ${ }^{5}$ (which would in principle bear a resemblance to the process of a sugarcane-derived vodka), may be explained by its distillation in a single distillation column, with a limited number of trays (15-20), to ensure the desirable cachaça flavor is retained. ${ }^{25}$ In fact, during the profiling of three major column still cachaça distilleries in Pernambuco State, Northeast Brazil, it was observed that cachaça passed through a single distillation column containing an average of 19 trays; the final spirit was collected at $47 \%$ vol. in all three distilleries. ${ }^{26}$ This is generally in contrast to distilleries producing neutral spirits (used in the preparation of beverages such as vodka and gin), where extractive and rectifying columns bear about 40 and 75 trays, respectively, and final spirit is collected at $95 \%$ vol. $^{23}$ 


\section{CONCLUSIONS}

This work has shown that all collected vodka samples produced in Brazil complied with the Brazilian regulations for total congeners and contaminants (methanol, copper, and lead). With regard to ethyl carbamate (EC) in vodka, unregulated in Brazil, all samples contained below $0.01 \mathrm{mg} / \mathrm{L}$ (analytical detection limit) and therefore complied with the international upper limit $(0.15 \mathrm{mg} / \mathrm{L})$ established or recommended by several countries for distilled spirits. Considering that a large proportion of Brazilian vodkas are made from sugarcane, it can be assumed that volatile cyanide and other possible nitrogen EC precursors present in sugarcane are adequately fixed by distillation apparatuses, most likely via a column rectification system. The implementation of EC regulations for Brazilian vodka is therefore not relevant at present. Another larger study is currently underway to investigate other alcoholic beverages from Brazil (e.g. rum, whisky, brandy, sake, mixed spirit drinks) that may contain EC.

\section{ACKNOWLEDGEMENTS}

ICCN and EVSP thank the CNPq (Edital 14/2009; Project No. 474644/2009-0) and FACEPE (Edital 12/2009; PBPG-0318-5.07/09) for financial support.

\section{REFERENCES}

1. IARC Working Group on the Evaluation of Carcinogenic Risks to Humans. Alcohol consumption and ethyl carbamate. IARC Monogr. Eval. Carcinog. Risks Hum. 2010, 96, 1428.

2. European Food Safety Authority. EFSA J. 2007, 551, 44.

3. Jones, D. A.; Phytochemistry 1998, 47, 155

4. Lachenmeier, D. W.; Schehl, B.; Kuballa, T.; Frank, W.; Senn, T.; Food Addit. Contam. 2005, 22, 397.

5. Lachenmeier, D. W.; Lima, M. C. P.; Nóbrega, I. C. C.; Pereira, J. A. P.; Kerr-Corrêa, F.; Kanteres, F.; Rehm, J.; BMC Cancer 2010, 10, 266. <http://www.biomedcentral.com/1471-2407/10/266>

6. Andrade-Sobrinho, L. G.; Boscolo, M.; Lima-Neto, B. D.; Franco, D. W.; Quim. Nova 2002, 25, 1074.

7. Barcelos, L. V. F.; Cardoso, M. G.; Vilela, F. J.; dos Anjos, J. P.; Quim. Nova 2007, 30, 1009.

8. Labanca, R. A.; Glória, M. B. A.; Afonso, R. J. C. F.; Quim. Nova 2008, $31,1860$.

9. Instrução Normativa $\mathrm{N}^{\circ} 13$ de 29 de junho de 2005 do Ministério da Agricultura, Pecuária e Abastecimento do Brasil. Diário Oficial da União 2005, 124, Seção 1, p. 3-4.
10. Lachemeier, D. W.; Ganss, S.; Rychlak, B.; Rehm, J.; Sulkowska, U.; Sdiba, M.; Zatonski, W.; Alcohol Clin. Exp. Res. 2009, 33, 1757.

11. Lachenmeier, D. W.; Anh, P. T. H.; Popova, S.; Rehm, J.; Int. J. Environ. R. Public Health 2009, 6, 2090.

12. Lachenmeier, D. W.; Samokhvalov, A.V.; Leitz, J.; Schoeberl, K.; Kuballa, T.; Linskiy, I.V.; Minko, O. I.; Rehm, J.; Food Chem. Toxicol. 2010, 48, 2842.

13. Lachenmeier, D.W.; Sarsh, B.; Rehm, J.; Alcohol and Alcoholism 2009, $44,93$.

14. Portaria No 63 de 23 de abril de 2008 do Ministério da Agricultura, Pecuária e Abastecimento do Brasil. Diário Oficial da União 2008, 78, Seção 1,8 .

15. Decreto $N^{\circ} 6.871$ de 4 de junho de 2009 da Presidência da República do Brasil. Diário Oficial da União 2009, 106, Seção 1, 26.

16. Regulation (EC) No. 110/2008 of the European Parliament and of the Council of 15 January 2008. Official Journal of the European Union 2008, L39, 16

17. Nóbrega, I. C. C.; Pereira, J. A. P.; Paiva, J. E.; Lachenmeier, D. W.; Food Chem. 2009, 117, 693.

18. Caldas, N. M., Raposo, J. L., Gomes Neto, J. A.; Barbosa Jr, F.; Food Chem. 2009, 113, 1266.

19. Ströhmer, G. In Spirituosen-Technologie; Kolb, E.; ed.; Behr's Verlag: Hamburg, 2002, p. 56.

20. Lachenmeier, D. W.; Attig, R.; Frank, W.; Athanasakis, C.; Eur. Food Res. Technol. 2003, 218, 105.

21. Lachenmeier D.W., Haupt S., Schulz K.; Regul. Toxicol. Pharmacol. 2008, 50, 313 .

22. Aylott, R. I.; Cochrane, G. C.; Leonard, M. J.; MacDonald, L. S.; MacKenzie, W. N.; McNeish, A. S.; Walker, D. A.; J. Inst. Brew. 1990, 96, 213.; MacKenzie, W. N.; Clyne, A. H.; MacDonald, L. S.; J. Inst. Brew. 1990, 96, 223.; Aresta, M.; Boscolo, M.; Franco, D. W.; J. Agric. Food Chem. 2001, 49, 2819.; Bruno, S. N. F.; Vaitsman, D. S.; Kunigami, C. N.; Brasil, M. G.; Food Chem. 2007, 104, 1345.

23. Murtagh, J. E. In The alcohol textbook: a reference for the beverage, fuel and industrial alcohol industries; Jacques, K.; Lyons, T.P.; Kelsall, D. R., eds.; Nottingham University Press: Nottingham, 1999, p. 95.

24. Park, S-R.; Ha, S-D.; Yoon, J-H.; Lee, S-Y.; Hong, K-P.; Lee E-H.; Yeom, H-J.; Yoon, N-G.; Bae D-H.; Food Control 2009, $20,946$.

25. Bruno, S. N. F. In Distillation - Advances from modeling to applications; Zereshki, S., ed. Intech, 2012, 159. Available from: http:// www.intechopen.com/books/distillation-advances-from-modeling-toapplications

26. Pereira, J. A. P.; M.Sc. Dissertation, Universidade Federal Rural de Pernambuco, Brazil, 2010. 